\title{
EKPLORASI LINGKUNGAN PESISIR KALIANGET SEBAGAI MEDIA PEMBELAJARAN PENUNJANG PEMBELAJARAN IPA KONSTEKTUAL
}

\author{
Herowati $^{1 *}$, Lutfiana Fazad Azizah ${ }^{2}$ \\ Fakultas Keguruan dan Ilmu Pendidikan Universitas Wiraraja ${ }^{1,2}$ \\ *corresponding Author : herowati.fkip@wiraraja.ac.id ${ }^{1}$
}

DOI: 10.24929/lensa.v10i2.120

Received: 5 November 2020

Revised: 20 November 2020

Accepted: 20 November 2020

\begin{abstract}
ABSTRAK
Penelitian ini bertujuan mendeskripsikan lingkungan pesisir Kalianget Kabupaten Sumenep untuk dapat dikembangkan menjadi buku petunjuk media pembelajaran IPA berbasis lingkungan pesisir. Model yang digunakan dalam penelitian ini adala ADDIE yang terdiri dari analisis (analysis), desain (design), pengembangan (development), implementasi (implementation), dan evaluasi (evaluation). Penelitian ini terbatas pada tahap analisis, desain, dan pengembangan. Hasil penelitian berupa kelayakan buku petunjuk media pembelajaran IPA berbasis lingkungan pesisir didapatkan dari hasil validasi aspek materi memperoleh hasil ratarata presentase $86 \%$ dengan nilai indeks kesepakatan ahli 0,86 dengan kategori sangat valid, validasi aspek desain memperoleh hasil $95 \%$, dan respon guru memperoleh hasil $90 \%$ dengan kategori sangat layak sehingga buku petunjuk media pembelajaran IPA berbasis lingkungan pesisir dapat digunakan.
\end{abstract}

Kata kunci: Buku Petunjuk, Media IPA, Pesisir

\section{ABSTRACT}

This study aims to describe the coastal environment of Kalianget in Sumenep Regency so that it can be developed into a manual for learning media for learning media based on coastal environments. This type of research uses the ADDIE model which consists of analysis, design, development, implementation, and evaluation. This research is limited to the analysis, design and development stages. The results obtained were the feasibility of a coastal environmentbased science learning media manual, obtained from the validation of the material aspects, obtaining an average percentage of $86 \%$ with an expert agreement index value of 0.86 with a very valid category, the validation of the design aspects obtained $95 \%$ results, and the response of the teacher obtained $90 \%$ results in the very feasible category so that the manual for learning media for natural science based on coastal environments could be used.

Keywords: Manuals, Natural Science Media, Coastal

\section{PENDAHULUAN}

Pembelajaran IPA dapat diterapkan secara kontekstual untuk membantu siswa menyelesaikan masalah yang ditemukan dalam kehidupan sehari-hari. Pembelajaran IPA merupakan salah satu pelajaran yang banyak pengaplikasiannya dalam kehidupan sehari-hari (Sulfiah and Sulisworo, 2016) dan dapat diterapkan secara kontekstual (Permana and Nourmavita, 2017). Proses belajar mengajar IPA yang diterapkan guru belum dikaitkan dengan kehidupan sehari-hari sehingga menyebabkan siswa tidak dapat menerapkannya di lingkungan. Hal ini akan menyebabkan siswa tidak dapat berpikir kritis (Handhika, 2012) dan penurunan prestasi (Indriati and Riskiyah, 2017).

Kurikulum 2013 mengarahkan pembelajaran diterapkan secara kontekstual (Pramita et all., 2018). Pada pelajaran IPA mengharuskan guru untuk tidak mendominasi di dalam kelas dan menerapkan proses pembelajaran dengan pendekatan kontekstual (Septiana, et all., 2018). Namun, realita yang banyak terjadi malah sebaliknya, sehingga salah satu solusi yang dapat dilakukan guru untuk 
menghadapi tantangan pendidikan dan masalah tersebut adalah memanfaatkan media pembelajaran yang tepat. Hal ini ditegaskan dari hasil penelitian yang banyak membuktikan efektivitas pemanfaatan media dalam proses pembelajaran berdampak pada peningkatan prestasi, motivasi, keterampilan, penguasaan konsep, dan berpikir kritis siswa (Istitho'ah, 2016). Keberhasilan pembelajaran IPA tidak hanya ditentukan dengan pemahaman dan aktivitas siswa yang tinggi (Mutia et all., 2017) melainkan juga faktor guru dalam menyelenggarakan pembelajaran dan penggunaan media pembelajaran yang tepat (Prasetyo et all., 2016). Siswa tidak sadar bahwa apa yang dilakukan dalam kegiatan sehari-hari merupakan aplikasi dari pelajaran IPA sehingga peran guru diperlukan untuk menerapkan pembelajaran IPA yang sesuai dengan kehidupan sehari-hari siswa. Guru perlu menggunakan media pembelajaran IPA atau memanfatkan lingkungan sekitar sebagai media pembelajaran yang dikembangkan sesuai karakteristik lingkungan sosial, budaya, geografis, dan latar belakang keluarga (Zuhri and Rizaleni, 2016) karena lingkungan dapat mendukung pencapaian tujuan pembelajaran (Musfiqon, 2012) serta membantu siswa membangun pengetahuannya sendiri melalui pengalaman langsung (Trianto, 2015).

Hasil triangulasi sumber dan teknik diperoleh fakta bahwa aktivitas bermain siswa di Kalianget berkaitan dengan alam salah satunya adalah aktivitas mencari kerang (cong-cong) pada saat laut surut (asat), hal ini dapat dikaitkan dengan materi pembelajaran IPA yaitu klasifikasi benda. Lingkungan pesisir merupakan potensi yang dapat dijadikan sebagai media pembelajaran yang mendukung pembelajaran IPA konstektual. Triangulasi teknik prapenelitian (Januari- April 2019) di SMPN 2 Kalianget, guru hanya menerapkan pembelajaran IPA kontekstual terhadap lingkungan secara umum. Tugas dan latihan soal yang diberikan juga tidak menuntut siswa untuk menghubungkan dengan kehidupan sehari-hari di lingkungan pesisir. Papan tulis dan LKS lebih sering digunakan sebagai media dalam kegiatan pembelajaran dengan alasan salah satunya merasa kesulitan menemukan buku petunjuk dan rujukan dalam memanfaatkan lingkungan pesisir sekitar siswa sebagai media untuk mendukung pembelajaran IPA secara kontekstual. eksplorasi potensi lingkungan wilayah pesisir Kalianget dibutuhkan sebagai media pembelajaran IPA SMP untuk mendukung penerapan pembelajaran kontekstual di kawasan pesisir Kalianget Kabupaten Sumenep karena dapat dijadikan buku petunjuk dan rujukan oleh guru dalam memanfaatkan lingkungan pesisir sebagai media pembelajaran yang sesuai dengan karakteristik siswa.

Berdasarkan paparan dan permasalahan di atas, maka penelitian ini bertujuan mendeskripsikan lingkungan pesisir Kalianget Kabupaten Sumenep untuk dapat dikembangkan menjadi buku petunjuk media pembelajaran IPA berbasis lingkungan pesisir.

\section{METODE}

Metode yang digunakan dalam penelitian terdiri dari dua tahap. Tahap pertama menggunakan metode studi kasus. Studi Kasus dalam penelitian ini digunakan untuk melakukan eksplorasi lingkungan di Kecamatan Kalianget. Sumber data utama adalah data hasil observasi lingkungan di pesisir Kecamatan Kalianget. Tahap kedua adalah mengembangakan hasil studi kasus eksplorasi lingkungan pesisir menjadi buku petunjuk media pembelajaran IPA berbasis lingkungan pesisir sebagai buku rujukan untuk guru dalam menerapkan pembelajaran kontekstual. Model penelitian menggunakan model penelitian pengembangan ADDIE yang terdiri dari analisis (analysis), desain (design), pengembangan (development), implementasi (implementation), dan_evaluasi (evaluation). Penelitian ini hanya sampai pada tahapan ketiga yaitu analisis (analysis), desain (design), pengembangan (development) dikarenakan keterbatasan waktu dan tenaga.

1. Tahapan Analisis (Analysis)

Peneliti menganalisis perlunya media yang akan dikembangkan. Tahap analisis terdiri dari analisis kebutuhan dan analisis kurikulum. 
a. Analisis Kebutuhan

Tahap ini dilakukan untuk mengetahui media pembelajaran yang digunakan dalam pembelajaran IPA kontekstual. Tahap ini melakukan pengembangan media yang bisa mendukung guru untuk menerapkan pembelajaran IPA kontekstual di pesisir kecamatan Kalianget.

b. Analisis kurikulum

Analisis kurikulum dilakukan untuk memperhatikan karakteristik kurikulum yang digunakan sekolah agar pengembangan yang media dapat sesuai tuntutan kurikulum yang berlaku. Peneliti kemudian melakukan analisis silabus pembelajaran IPA kelas VII untuk mengetahui materi yang sesuai diajarkan secara kontekstual dengan memanfaatkan media yang ada di lingkungan pesisir Kecamatan Kalianget.

2. Tahap Perancangan (Design)

Pada perancangan mulai dirancang buku petunjuk media pembelajaran IPA berbasis lingkungan pesisir yang akan dikembangkan sesuai hasil analisis silabus yang sudah dilakukan. Selanjutnya, ditentukan unsur-unsur yang diperlukan dalam buku petunjuk. Peneliti juga mengumpulkan daftar referensi yang akan digunakan untuk mengembangkan materi dalam buku petunjuk media pembelajaran IPA berbasis lingkungan pesisir. Peneliti kemudian menyusun instrumen yang akan digunakan untuk menilai buku petunjuk yang dikembangkan. Instrumen disusun dengan memperhatikan aspek penilaian buku petunjuk yaitu aspek kelayakan isi dan kelayakan penyajian. Instrumen berupa angket validasi dan respon.

\section{Instrumen Pengumpulan Data}

Instrument pengumpulan data berupa lembar validasi buku petunjuk media pembelajaran IPA berbasis lingkungan pesisir yang digunakan untuk mendapatkan data kelayakan isi dari buku kerja yang dikembangkan. Data tersebut diperoleh dari penilaian ahli desain dan ahli materi. Instrument validasi materi dapat dilihat pada tabel 1 dan Instrumen validasi desain media dapat dilihat pada tabel 2.

Tabel 1. Instrumen Validasi Materi Buku Petunjuk Media Pembelajaran IPA Berbasis Lingkungan Pesisir

\begin{tabular}{cc} 
No. & Indikator \\
\hline 1 & Materi sesuai dengan kompetensi dasar pembelajaran IPA \\
\hline 2 & Materi sesuai dengan capaian akhir pembelajaran Kompetensi pembelajaran IPA \\
\hline 3 & $\begin{array}{c}\text { Materi mencerminkan jabaran kompetensi dasar pembelajaran IPA dengan } \\
\text { memanfaatkan lingkungan sekitar (kontekstual) }\end{array}$ \\
\hline 4 & $\begin{array}{c}\text { Materi meliputi bidang kajian media untuk pembelajaran IPA berbasis lingkungan } \\
\text { pesisir }\end{array}$ \\
\hline 5 & Materi meliputi bidang kajian pembelajaran IPA berbasis lingkungan pesisir \\
\hline 6 & Kegiatan pada buku petunjuk sesuai dengan lingkungan sekitar (kontekstual) \\
\hline 7 & Sesuai dengan kaidah Bahasa Indonesia \\
\hline 8 & Kalimat memiliki struktur S-P-O-K (subjek-predikat-objek-keterangan) \\
\hline 9 & Kalimat tidak ambigu \\
\hline (Sumber: mengadaptasi dari Mujiono dan dikembangkan oleh peneliti) \\
Tabel & 2. Instrument Validasi Desain Buku Petunjuk Media Pembelajaran \\
IPA Berbasis Lingkungan Pesisir \\
No. & Indikator \\
\hline 1 & Gambar sampul sesuai dengan judul buku petunjuk media pembelajaran IPA \\
\hline 2 & Judul buku menjadi pusat pandang \\
\hline 3 & Warna tulisan judul buku kontras dengan warna background \\
\hline 4 & Penempatan gambar tidak mengganggu tulisan \\
\hline 5 & Penggunaan variasi huruf (bold, italic, all capital, small capital) konsisten \\
\hline 6 & Spasi teks konsisten \\
\hline 7 & Ukuran gambar sesuai dengan resolusi
\end{tabular}




\begin{tabular}{cl}
8 & Gambar memuat nomor dan judul \\
\hline 9 & Warna gambar realistis \\
\hline 10 & Bentuk gambar realistis
\end{tabular}

(Sumber: mengadaptasi dari Mujiono dan dikembangkan oleh peneliti)

Instrument pengumpulan data kedua yaitu angket respon yang digunakan untuk mengetahui respon guru terhadap buku dikembangkan. Angket respon guru berisi pernyataan-pernyataan yang harus dipilih oleh guru dengan memberikan jawaban iya atau tidak. Instrumen respon guru dapat dilihat pada tabel 3 berikut:

\section{Tabel 3. Angket Respon Guru}

\begin{tabular}{cccc} 
No. Pernyataan \\
\hline 1 & $\begin{array}{c}\text { Gambar yang digunakan memperjelas buku petunjuk media pembelajaran IPA } \\
\text { berbasis lingkungan pesisir }\end{array}$ \\
\hline 2 & $\begin{array}{c}\text { Contoh kegiatan eksplorasi lingkungan pesisir pada buku petunjuk media } \\
\text { pembelajaran IPA mudah ditemui di lingkungan siswa untuk mendukung } \\
\text { pembelajaran IPA secara kontekstual }\end{array}$ \\
\hline 3 & $\begin{array}{c}\text { Penyajian materi pada buku petunjuk media pembelajaran IPA berbasis } \\
\text { lingkungan pesisir tersusun sistematis }\end{array}$ \\
\hline 4 & $\begin{array}{c}\text { Tampilan buku petunjuk media pembelajaran IPA berbasis lingkungan pesisir } \\
\text { menarik }\end{array}$ \\
\hline 5 & Bahasa yang digunakan mudah dipahami \\
\hline 7 & $\begin{array}{c}\text { Buku petunjuk media pembelajaran IPA berbasis lingkungan pesisir mudah } \\
\text { dibawa }\end{array}$ \\
\hline 8 & $\begin{array}{c}\text { Buku petunjuk media pembelajaran IPA berbasis lingkungan pesisir memfasilitasi } \\
\text { guru untuk menggali informasi media yang ada di lingkungan pesisir }\end{array}$ \\
\hline $\begin{array}{c}\text { Buku petunjuk media pembelajaran IPA berbasis lingkungan pesisir membantu } \\
\text { guru untuk menemukan media yang dibutuhkan dalam mendukung pembelajaran } \\
\text { IPA kontekstual }\end{array}$ \\
\hline $\begin{array}{c}\text { Contoh eksplorasi lingkungan pesisir sebagai rujukan media pembelajaran yang } \\
\text { ada di buku petunjuk media pembelajaran IPA berbasis lingkungan pesisir mudah } \\
\text { ditemukan di lingkungan pesisir }\end{array}$ \\
\hline 10 & $\begin{array}{c}\text { Buku petunjuk media pembelajaran IPA berbasis lingkungan pesisir membantu } \\
\text { guru untuk menerapkan pembelajaran IPA kontekstual berbasis lingkungan } \\
\text { pesisir }\end{array}$ \\
\hline
\end{tabular}

(Sumber: mengadaptasi dari Mujiono dan dikembangkan oleh peneliti)

\section{Tahap Pengembangan (Development)}

Tahap ini merupakan tahap realisasi produk buku petunjuk. Pengembangan buku petunjuk media pembelajaran IPA berbasis lingkungan pesisir dilakukan sesuai dengan yang telah rancang. Setelah itu, buku petunjuk tersebut akan divalidasi oleh validator ahli. Validasi dilakukan untuk menilai validitas isi dan desain. Validator memberikan penilaian pada buku petunjuk yang dikembangkan berdasarkan pernyataan aspek kelayakan buku petunjuk serta memberikan saran dan komentar berkaitan dengan isi buku petunjuk media pembelajaran IPA berbasis lingkungan pesisir. Hasilnya akan digunakan sebagai rujukan untuk melakukan perbaikan buku petunjuk. Proses Validasi dilakukan sampai buku petunjuk dinyatakan layak untuk digunakan sebagai petunjuk media.

\section{Validasi Kelayakan Isi}

Kelayakan isi dari buku petunjuk media pembelajaran IPA berbasis lingkungan pesisir divalidasi oleh validator ahli menggunakan instrumen validasi yang telah disusun. Instrumen validasi isi terdiri dari validasi isi materi (10 butir pernyataan) dan validasi isi desain (10 butir pernyataan) yang harus diisi oleh validator. Validator desain terdiri dari 2 orang ahli sedangkan validator materi terdiri dari 3 orang ahli. Menurut (Retnawati, 2015) jika validasi isi akan dikuantifikasi, minimal harus ada 3 ahli yang dilibatkan sebagai validator. Berdasarkan hasil penilaian 3 ahli, kemudian dihitung indeks kesepakatan ahli atau kesepakatan validator menggunakan indeks Aiken. 


\section{Teknik Analisis Data}

1) Analisis Validasi materi.

Kriteria \% $=\frac{\mathbf{A}}{\mathbf{B}} \times 100 \%$

Keterangan:

A : Jumlah nilai validator

B : Skor maksimal

Tabel 4. Kriteria Presentase Kelayakan

\begin{tabular}{cc}
\hline Persentase Kelayakan & Kategori \\
\hline$<20 \%$ & Tidak layak \\
\hline $21 \%-40 \%$ & Kurang layak \\
\hline $41 \%-60 \%$ & Cukup layak \\
\hline $61 \%-80 \%$ & Layak \\
\hline $81 \%-100 \%$ & Sangat layak \\
\hline
\end{tabular}

Sumber: mengadaptasi dari Setiawan and Wiyardi, 2015

\section{Indeks Kesepakatan Ahli}

Validitas isi ditentukan menggunakan kesepakatan ahli. Hasil penilaian kesepakatan ahli dapat dihitung dengan indeks validitas, yaitu indeks Aiken. Indeks Aiken dirumuskan sebagai berikut:

$$
V=\frac{\Sigma s}{n(c-1)}
$$

$\mathrm{V}=$ indeks kesepakatan rater tentang validitas butir

$\mathrm{s}=$ skor yang ditetapkan pada setiap rater dikurangi skor terendah dalam kategori yang dipakai $\left(s=r-I_{o}\right)$

$r=$ skor kategori pilihan rater dan lo skor terendah dalam kategori penyekoran)

$\mathrm{n}$ = banyaknya rater

$c=$ banyaknya kategori yang dapat dipilih rater.

Dari hasil perhitungan indeks $V$, suatu butir dapat dikategorikan berdasarkan indeknya. Jika hasilnya kurang atau sama dengan 0,4 dikatakan validitasnya kurang, 0,4 sampai 0,8 dikatakan validitasnya sedang, dan jika lebih besar dari 0,8 dikatakan sangat valid (Retnawati, 2015).

2) Analisis Validasi Desain Produk

Kriteria \% $=\frac{\mathbf{A}}{\mathbf{B}} \times 100 \%$

Keterangan:

A : Jumlah nilai yang diperoleh

B : Skor maksimal

Tabel 5. Kriteria Presentase Kelayakan

\begin{tabular}{cc}
\hline Persentase Kelayakan & Kategori \\
\hline$<20 \%$ & Tidak layak \\
\hline $21 \%-40 \%$ & Kurang layak \\
\hline $41 \%-60 \%$ & Cukup layak \\
\hline $61 \%-80 \%$ & Layak \\
\hline $81 \%-100 \%$ & Sangat layak
\end{tabular}

Sumber: (Setiawan and Wiyardi, 2015)

\section{Analisis Respon Guru}

Respon guru dilihat dari hasil sebaran angket. Data respon guru dianalisis menggunakan Rumus:

$$
\text { Persentase respon guru }=\frac{\text { Total skor jawaban }}{\text { Skor maksimal }} \times 100 \%
$$


Tabel 6. Kriteria Respon Guru

\begin{tabular}{cc}
\hline Persentase Respon Guru & Kriteria \\
$85<\mathrm{RS} \leq 100$ & Sangat Baik \\
\hline $65<\mathrm{RS} \leq 85$ & Baik \\
\hline $45<\mathrm{RS} \leq 65$ & Cukup Baik \\
\hline $0 \leq \mathrm{RS} \leq 45$ & Tidak Baik
\end{tabular}

Sumber: mengadaptasi dari Wulandari, 2017

\section{HASIL DAN PEMBAHASAN}

\section{Deskripsi Lingkungan di Kecamatan Kalianget}

Eksplorasi lingkungan Kecamatan Kalianget dilakukan dengan observasi langsung untuk mendapatkan data sesuai fakta dan informasi objektif. Observasi langsung dilakukan di 7 Desa yang ada di Kecamatan Kalianget yaitu Pinggir Papas, Karanganyar, Marengan Laok, Kertasada, Kalimo'ok, Kalianget Barat dan Kalianget Timur.

Desa Pinggir Papas dan Karanganyar merupakan 2 Desa yang memiliki kondisi serta karakteristik lingkungan yang sama karena letak dari ke dua Desa ini bersebelahan. Kondisi lingkungan dari kedua Desa ini sama-sama di dominasi oleh tambak garam dan pantai. Desa Karanganyar dan Pinggir Papas termasuk dalam kedua Desa yang memiliki lahan tambak garam terbesar di kecamatan Kalianget jika dibandingkan dengan 5 desa yang lain. Desa Marengan Laok adalah Desa yang berada di sebelah utara Desa Karanganyar. Desa Marengan Laok memiliki karakteristik dan kondisi Desa yang hampir sama dengan Karanganyar dan Pinggir Papas. Tambak garam dan pantai mendominasi desa Marengan Laok meskipun keberadaan tambak garam di desa Marengan Laok tidak seluas desa Karanganyar dan Pinggir Desa Kalimo'ok adalah Desa yang terletak di sebelah timur dari Marengan Laok. Desa Kalimo'ok memiliki lahan tambak garam, pantai, dan perkebunan seperti jagung, padi, dan pisang. Desa Kertasada memiliki lahan tambak garam yang luas dan lahan perkebunan seperti mangga dan jagung, serta budi daya lebah sebagai penghasil madu. Desa Kalianget Barat memiliki lahan tambak garam dan di dominasi oleh lahan perkebunan seperti jagung, padi, pisang, dan mangga. Sebelah timur dari Kecamatan kalianget adalah Desa Kalianget Timur. Desa Kalianget timur selain di memiliki lahan tambak garam juga memiliki lahan perkebunan yang luas menjadi. Desa ini juga memiliki sarana transportasi laut untuk akses transportasi ke pulau atau kecamatan lain yang ada di timur seperti Talango. Desa Kalianget Barat dan Kalianget Timur juga memiliki ekosistem mangrove terbanyak dibandingkan 5 desa yang lain. Dengan demikian dapat disimpulkan bahwa kondisi di Kecamatan Kalianget di dominasi oleh keberadaan ekosistem mangrove, lahan tambak garam, dan pantai sehingga masyarakat setempat umumnya bekerja dengan memanfaatkan sumber daya yang ada disekitarnya baik itu sebagai petani (petani garam, perkebunan) dan nelayan.

Kecamatan Kalianget merupakan daerah penghasil garam terbesar di Kabupaten Sumenep dengan luas area lahan pegaraman sekitar 495,05 $\mathrm{Ha}$ (Suhelmi, dkk; 2013). Masyarakat yang bekerja sebagai petani garam lebih banyak melakukan aktivitas sehari-hari di tambak garam. Pekerjaan sebagai petani memiliki banyak tahapan beberapa diantaranya adalah aktivitas nolong yaitu aktivitas memanen garam di tambak, aktivitas nembheng aing yang merupakan aktivitas mengukur salinitas air garam, dan aktivitas ngetrek yaitu aktivitas mengangkut garam yang sudah di isi ke dalam karung menggunakan truk untuk dijual.

Di daerah pantai pesisir Kalianget, selain didominasi oleh lahan tambak dan pantai juga terdapat ekosistem khas yaitu ekosistem mangrove. Mangrove adalah jenis tumbuhan yang menjadi khas dari lingkungan pesisir. Mangrov adalah tumbuhan yang mampu hidup dan tumbuh di antara darat dan laut (Setyawan, Susilowati \& Sutarno, 2002). Dalam ekosistem pesisir pantai terdapat beranekaragam jenis tumbuhan atau tanaman yang bisa dijumpai seperti paku- 
pakuan, herba, semak, perdu ataupun pohon. Substrat tanah mempengaruhi jenis tumbuhan yang dapat tumbuh di daerah tersebut. Spesies tumbuhan mangrov dapat berbentuk monospesies (tunggal) atau spesies campuran yang terdapat pada garis pantai (Puryono dkk, 2019).

\section{Pengembangan Buku Petunjuk}

1) Hasil Analisis

a. Analisis Kebutuhan

Analisis kebutuhan dilakukan melalui observasi ke sekolah dan menganalisis media pembelajaran yang digunakan pada pembelajaran IPA. Hasil observasi mendapakan hasil bahwa guru tidak menerapkan pembelajaran kontekstual yang sesuai dengan kehidupan sehari-hari siswa di lingkungan pesisir Kalianget karena kesulitan menemukan buku petunjuk atau rujukan yang memanfaatkan lingkungan pesisir sebagai sumber media belajar bagi siswa. Pada tahap ini mengembangkan buku petunjuk media pembelajaran IPA berbasis lingkungan pesisir yang dapat dijadikan sebagai referensi atau rujukan bagi guru untuk melaksanakan pembelajaran IPA.

b. Analisis Kurikulum

Analisis ini dilakukan untuk mengetahui karakteristik kurikulum yang digunakan dalam sekolah agar pengembangan yang dilakukan dapat sesuai tuntutan kurikulum yang berlaku. Peneliti kemudian melakukan analisis silabus pembelajaran IPA kelas VII untuk mengetahui materi yang sesuai diajarkan secara kontekstual dengan memanfaatkan media yang ada di lingkungan pesisir Kecamatan Kalianget.

2) Deskripsi Produk

Pengembangan produk berupa buku petunjuk media pembelajaran IPA berbasis lingkungan pesisir. Deskripsi produk dapat dilihat pada Tabel berikut.

\section{Tabel 7. Deskripsi Buku Petunjuk Media Pembelajaran IPA Berbasis} Lingkungan Pesisir

\section{Gambar Keterangan}

Cover: Berisi nama penulis, judul yang
berfungsi untuk menunjukkan identitas dari
buku petunjuk dan gambar. Sampul berguna
untuk memperindah tampilan produk sehingga
menarik minat pembaca


Lensa (Lentera Sains): Jurnal Pendidikan IPA

Vol. 10, No. 2, hlm. 137-156, 2020

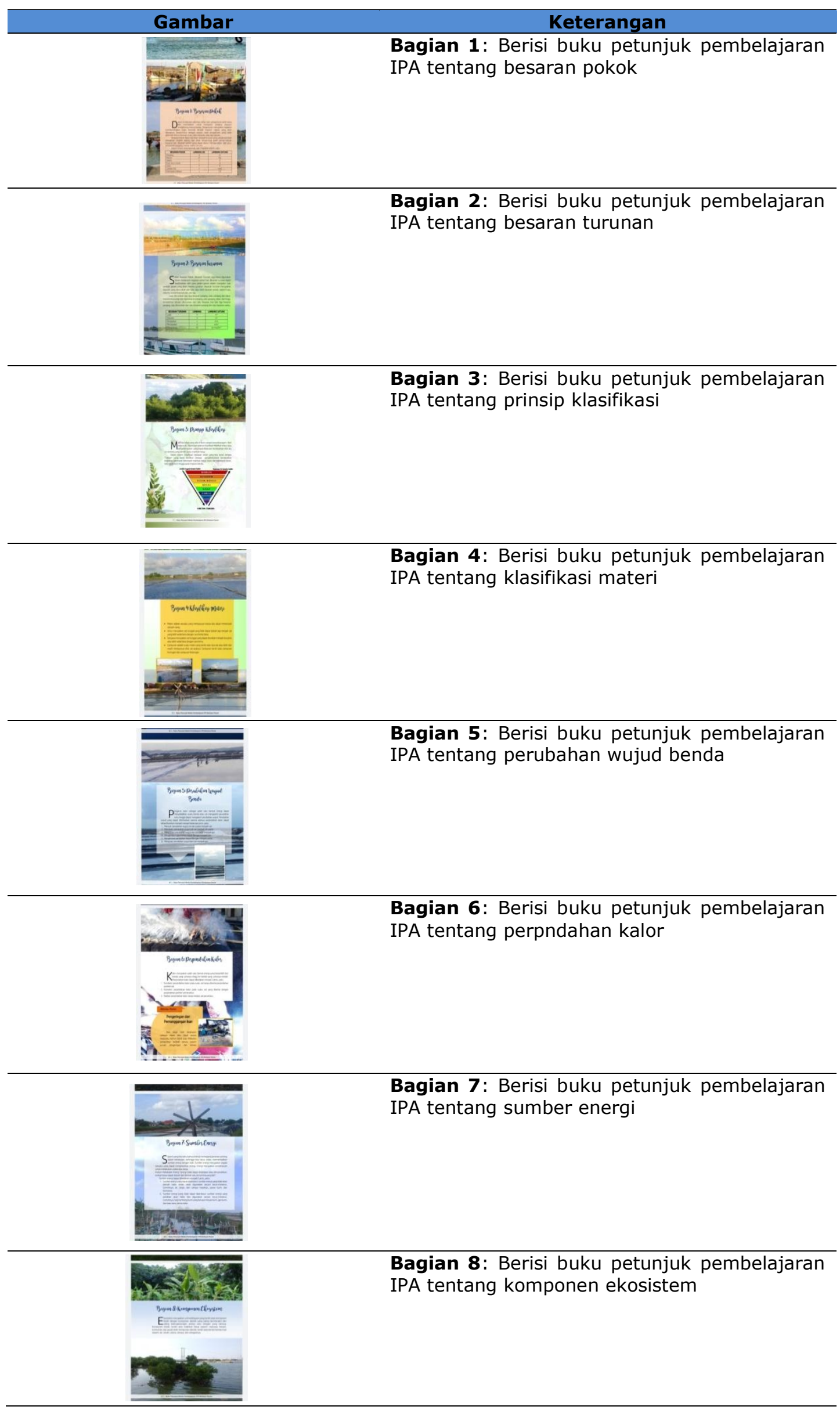




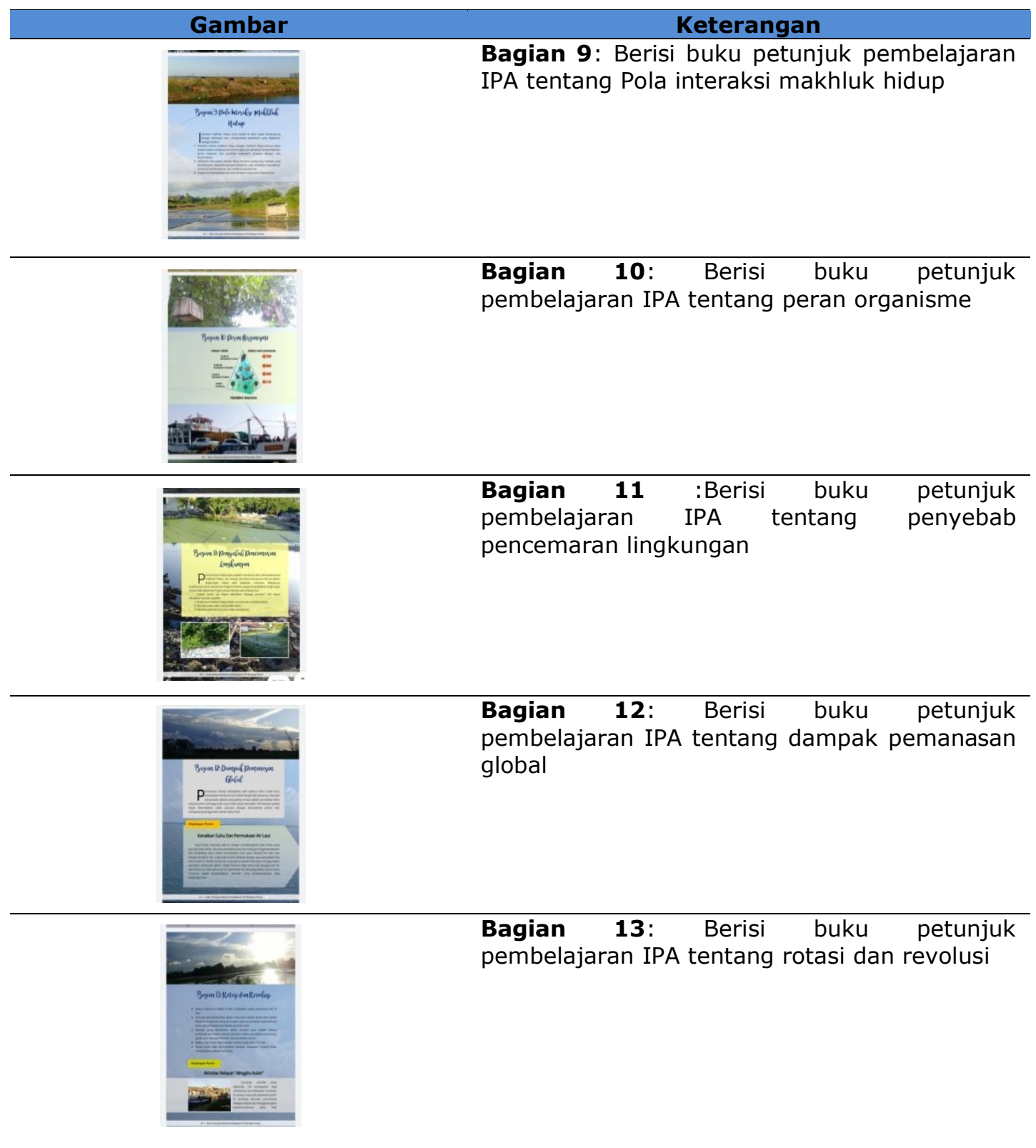

Sumber: Peneliti, diolah pada September 2020

3) Validasi Produk

Validasi produk digunakan untuk melihat kelayakan buku petunjuk media pembelajaran IPA berbasis lingkungan pesisir yang telah dikembangkan oleh peneliti. Kelayakan produk dalam penelitian dilakukan oleh 5 validator sesuai dengan keahliannya masing-masing, yaitu 2 orang validator desain, dan 3 orang validator media. Masing-masing validator tersebut memberikan penilaian kedalam angket kelayakan buku kerja yang telah persiapkan oleh peneliti. Hasil validasi buku kerja media pembelajaran berbasis lingkungan pesisir dapat dilihat pada tabel sebagai berikut: 
Tabel 8. Data Hasil Validasi Materi Buku Petunjuk Media Pembelajaran IPA Berbasis Lingkungan Pesisir

\begin{tabular}{|c|c|c|c|c|c|c|c|c|c|c|c|c|c|}
\hline \multirow{2}{*}{$\begin{array}{l}\text { Validator } \\
\text { Ahli }\end{array}$} & \multicolumn{12}{|c|}{ Jumlah Nilai Angket Produk Per Bagian } & \multirow{2}{*}{ Jumlah } \\
\hline & 1 & 2 & 3 & 4 & 5 & 6 & 7 & 8 & 9 & 10 & 11 & 12 & \\
\hline $\begin{array}{l}\text { Dyah Ayu } \\
\text { Fajarianingtia } \\
\text { S, M. Pd }\end{array}$ & 9 & 10 & 10 & 8 & 9 & 9 & 7 & 8 & 7 & 9 & 7 & 8 & 7 \\
\hline $\begin{array}{l}\text { Nisfil } \\
\text { Magfiroh } \\
\text { Meita, M.Pd }\end{array}$ & 10 & 10 & 10 & 9 & 9 & 10 & 7 & 8 & 8 & 8 & 9 & 9 & 7 \\
\hline $\begin{array}{l}\text { Ratih } \\
\text { Yuniastri, } \\
\text { S.Si., M. Pd }\end{array}$ & 10 & 10 & 8 & 9 & 8 & 10 & 8 & 9 & 8 & 9 & 9 & 9 & 7 \\
\hline Rata-Rata & $\begin{array}{c}9,6 \\
7\end{array}$ & $\begin{array}{c}10,0 \\
0\end{array}$ & $\begin{array}{c}9,3 \\
3\end{array}$ & $\begin{array}{c}8,6 \\
7\end{array}$ & $\begin{array}{c}8,6 \\
7\end{array}$ & $\begin{array}{c}9,6 \\
7\end{array}$ & $\begin{array}{c}7,3 \\
3\end{array}$ & $\begin{array}{c}8,3 \\
3\end{array}$ & $\begin{array}{c}7,6 \\
7\end{array}$ & $\begin{array}{c}8,6 \\
7\end{array}$ & $\begin{array}{c}8,3 \\
3\end{array}$ & $\begin{array}{c}8,6 \\
7\end{array}$ & 7,00 \\
\hline Presentase & $\begin{array}{l}97 \\
\%\end{array}$ & $\begin{array}{c}100 \\
\%\end{array}$ & $\begin{array}{l}93 \\
\% \\
\end{array}$ & $\begin{array}{l}87 \\
\% \\
\end{array}$ & $\begin{array}{l}87 \\
\% \\
\end{array}$ & $\begin{array}{l}97 \\
\% \\
\end{array}$ & $\begin{array}{l}73 \\
\%\end{array}$ & $\begin{array}{l}83 \\
\%\end{array}$ & $\begin{array}{l}77 \\
\%\end{array}$ & $\begin{array}{l}87 \\
\%\end{array}$ & $\begin{array}{l}83 \\
\%\end{array}$ & $\begin{array}{l}87 \\
\%\end{array}$ & $70 \%$ \\
\hline Kategori & $\begin{array}{c}\text { S. } \\
\text { Laya } \\
\text { k }\end{array}$ & $\begin{array}{c}\text { S. } \\
\text { Laya } \\
\text { k }\end{array}$ & $\begin{array}{l}\text { S. } \\
\text { Laya } \\
\text { k }\end{array}$ & $\begin{array}{l}\text { S. } \\
\text { Laya } \\
\text { k }\end{array}$ & $\begin{array}{l}\text { S. } \\
\text { Laya } \\
\text { k }\end{array}$ & $\begin{array}{l}\text { S. } \\
\text { Laya } \\
\text { k }\end{array}$ & $\begin{array}{c}\text { Laya } \\
\mathrm{k}\end{array}$ & $\begin{array}{c}\text { S. } \\
\text { Laya } \\
\text { k }\end{array}$ & $\begin{array}{c}\text { Laya } \\
\text { k }\end{array}$ & $\begin{array}{l}\text { S. } \\
\text { Laya } \\
\text { k }\end{array}$ & $\begin{array}{c}\text { S. } \\
\text { Laya } \\
\text { k }\end{array}$ & $\begin{array}{c}\text { S. } \\
\text { Laya } \\
\text { k }\end{array}$ & Layak \\
\hline
\end{tabular}

Sumber: Peneliti, diolah pada Oktober 2020

Kelayakan isi buku petunjuk media pembelajaran IPA berbasis lingkungan pesisir dilakukan melalui penyebaran angket kepada 3 validator. Angket validasi berisi 10 butir pernyataan yang diisi dengan jawaban iya atau tidak. Hasil validasi materi dari 3 validator mendapatkan rata-rata hasil presentase per bagian isi buku sebesar $86 \%$ dengan kategori sangat layak. Selain itu untuk mengetahui validitas isi produk dilakukan uji kesepakatan dari 3 validator. Indeks validitas digunakan untuk mengetahui kesepakatan ahli dari 3 validator. Hasil uji kesepakatan 3 validator dapat dilihat pada tabel sebagai berikut.

Tabel 9. Data Hasil Indeks Aiken Kesepakatan Validator Ahli

\begin{tabular}{cc} 
Bagian Buku & Index Aiken \\
\hline Bagian 1 & 0,97 \\
\hline Bagian 2 & 1,00 \\
\hline Bagian 3 & 0,93 \\
\hline Bagian 4 & 0,87 \\
\hline Bagian 5 & 0,87 \\
\hline Bagian 6 & 0,97 \\
\hline Bagian 7 & 0,73 \\
\hline Bagian 8 & 0,83 \\
\hline Bagian 9 & 0,77 \\
\hline Bagian 10 & 0,87 \\
\hline Bagian 11 & 0,83 \\
\hline Bagian 12 & 0,87 \\
\hline Bagian 13 & 0,70 \\
\hline Rata-rata & $\mathbf{0 , 8 6}$ \\
\hline Kategori & Tinggi
\end{tabular}

Sumber: Peneliti, diolah pada Oktober 2020

Hasil validitas isi dari dari kesepakatan 3 validator yang ditentukan dengan indeks validitas Aiken mendapat rata-rata nilai sebesar 0,86. Nilai 0,86 menunjukkan bahwa validitas isi produk masuk dalam kategori tinggi. Berdasarkan hasil penilaian tersebut, diketahui bahwa buku petunjuk media pembelajaran IPA berbasis lingkungan pesisir dikategorikan sangat layak dan guru dapat menggunakannya dalam pembelajaran. 
Data hasil validasi desain buku petunjuk media pembelajaran IPA berbasis lingkungan pesisir dapat dilihat pada tabel sebagai berikut:

Tabel 10. Data Hasil Validasi Desain Buku Petunjuk Media Pembelajaran IPA Berbasis Lingkungan Pesisir

\begin{tabular}{cc} 
Ahli Desain & Hasil Penilaian Desain \\
\cline { 2 - 2 } Taufikur Rahman, S. Kom., M. Kom. & Kualitas Fisik \\
\hline Arda Gusema Susilowati S. Kom., M. Kom. & 9 \\
\hline Rata-rata & 10 \\
\hline Persentase (\%) & 9,5 \\
\hline Kategori & $95 \%$ \\
\hline Sut & Sangat Layak
\end{tabular}

Sumber: Peneliti, diolah pada Oktober 2020

Hasil validasi desain memperoleh presentase rata-rata 95\% dengan kriteria sangat layak. Dari nilai tersebut, dapat diketahui bahwa buku petunjuk media pembelajaran IPA berbasis lingkungan pesisir dikategorikan sangat layak dan guru dapat menggunakannya dalam proses pembelajaran.

\section{Revisi Produk}

Revisi produk buku petunjuk dilakukan setelah divalidasi oleh para ahli. Komentar dan saran dari para ahli digunakan sebagai patokan melakukan revisi. Bagian buku yang direvisi berdasarkan hasil dari validator dapat dilihat pada Tabel berikut

Tabel 11. Revisi Materi Produk Buku Petunjuk Media Pembelajaran IPA Berbasis Lingkungan Pesisir

\begin{tabular}{|c|c|c|c|c|}
\hline No & $\begin{array}{c}\text { Nama } \\
\text { Validator }\end{array}$ & $\begin{array}{l}\text { Bagian } \\
\text { Revisi }\end{array}$ & Deskripsi Komentar & Hasil Perbaikan \\
\hline 1 & $\begin{array}{l}\text { Dyah Ayu } \\
\text { F., M.Pd. }\end{array}$ & Isi & $\begin{array}{l}\text { 1) Materi sudah sesuai } \\
\text { dengan silabus, namun } \\
\text { pembahasannya terlalu } \\
\text { sedikit/kurang } \\
\text { 2) Keterkaitan materi dan } \\
\text { lingkungan pesisir } \\
\text { sebaiknya langsung } \\
\text { dibahas secara } \\
\text { komprehensif } \\
\text { 3) Tidak mencantumkan } \\
\text { kutipan/rujukan teks } \\
\text { dalam isi buku }\end{array}$ & 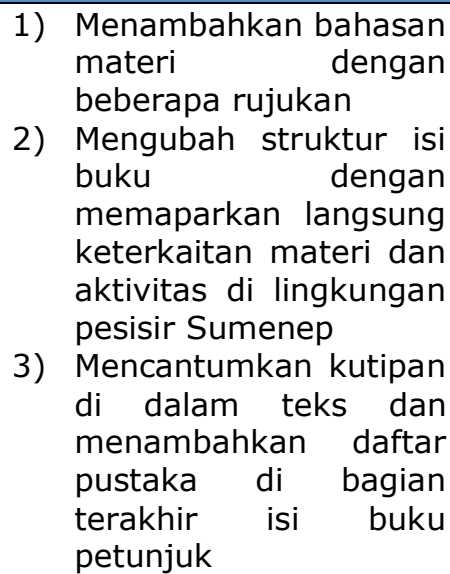 \\
\hline 2 & $\begin{array}{c}\text { Niasfil } \\
\text { Magfiroh } \\
\text { Meita, M.Pd }\end{array}$ & Isi & $\begin{array}{l}\text { 1) Isi materi dan } \\
\text { lingkungan pesisir tidak } \\
\text { dibahas dengan } \\
\text { rujukan } \\
\text { 2) Materi kurang } \\
\text { mendalam }\end{array}$ & $\begin{array}{l}\text { 1) Menambahkan rujukan } \\
\text { dan kutipan pada teks } \\
\text { 2) Menambahkan cakupan } \\
\text { bahasan materi terkait } \\
\text { dengan beberapa } \\
\text { rujukan }\end{array}$ \\
\hline 3 & $\begin{array}{c}\text { Ratih } \\
\text { Yuniastri, } \\
\text { S.Si., M. Pd }\end{array}$ & Isi & $\begin{array}{l}\text { 1) Hasil ekslorasi pesisir } \\
\text { dalam buku tidak } \\
\text { didukung } \\
\text { literatur dengan } \\
\text { 2) Materi kurang rinci }\end{array}$ & $\begin{array}{l}\text { 1) Menambahkan rujukan } \\
\text { dan kutipan pada teks } \\
\text { 2) Menambahkan materi } \\
\text { secara lebih jelas dan } \\
\text { rinci dari berbagai } \\
\text { rujukan }\end{array}$ \\
\hline
\end{tabular}

Saran dan komentar dari para ahli menjadi masukan untuk melakukan perbaikan terhadap buku petunjuk media pembelajaran IPA berbasis lingkungan 
Lensa (Lentera Sains): Jurnal Pendidikan IPA

Vol. 10, No. 2, hlm. 137-156, 2020

pesisir yang telah dibuat. Tabel .menunjukkan hasil perbaikan dari revisi atau saran ahli.

Tabel 12. Produk Sebelum dan Sesudah Revisi

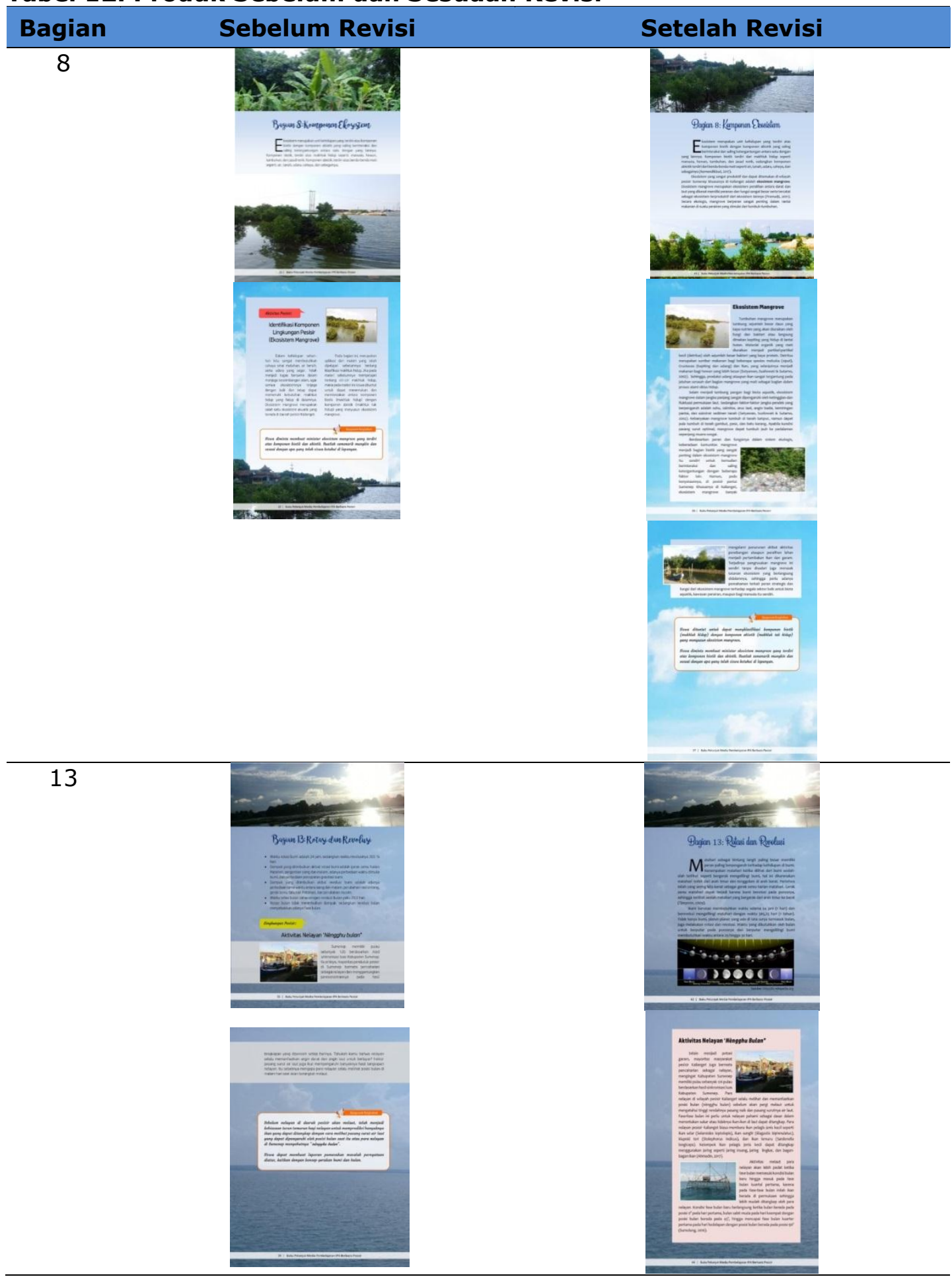




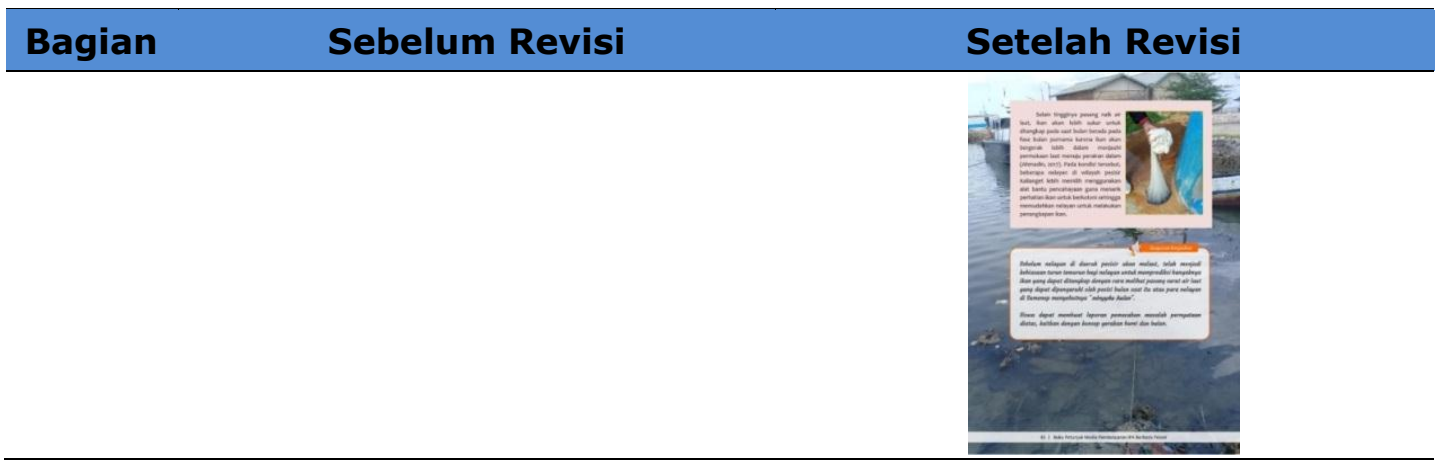

Sumber: Peneliti, diolah pada Oktober 2020

Tabel 13. Revisi Desain Produk buku Petunjuk Media Pembelajaran IPA Berbasis Lingkungan Pesisir

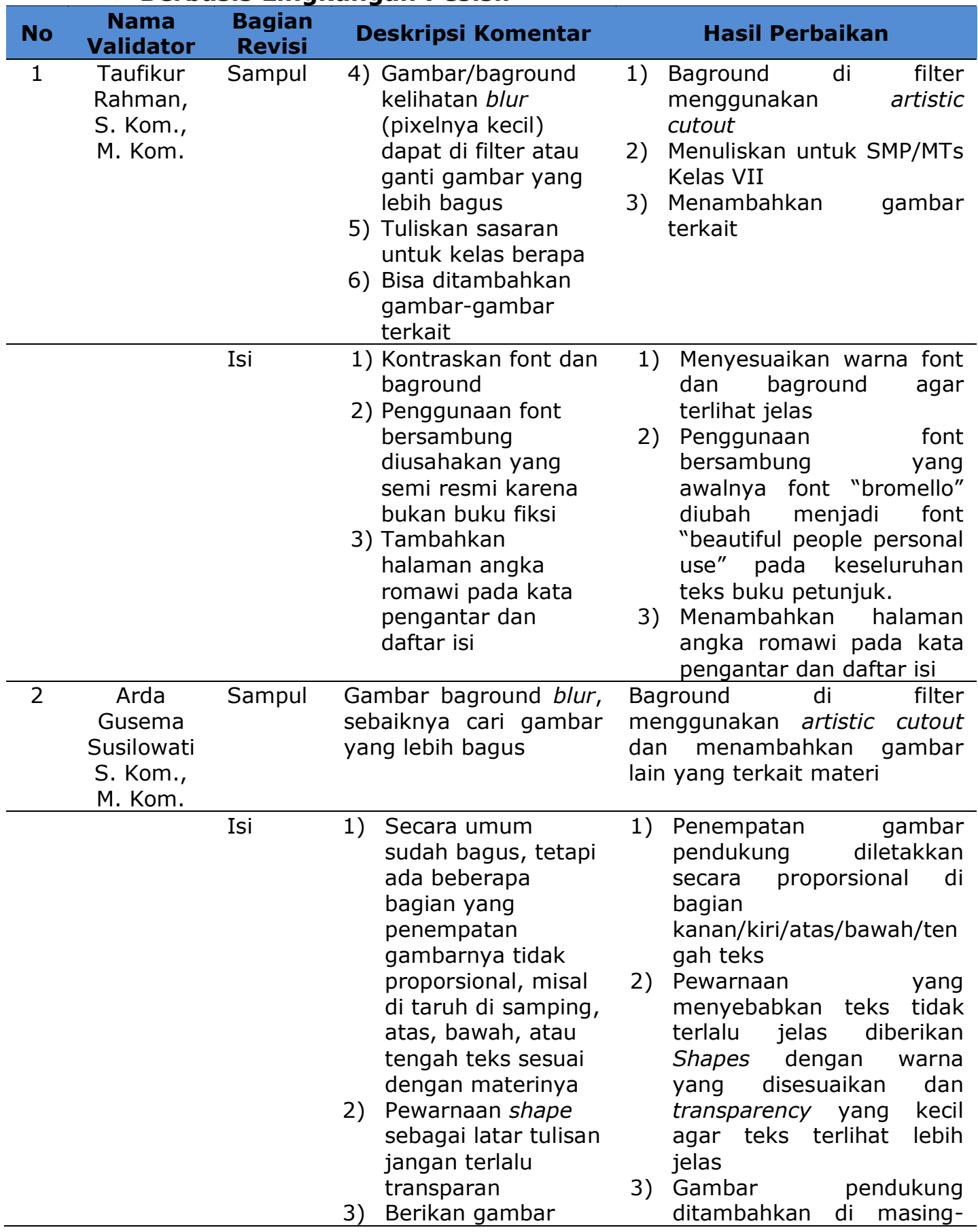




\begin{tabular}{ll}
$\begin{array}{l}\text { pendukung pada } \\
\text { teks }\end{array}$ & $\begin{array}{l}\text { masing teks bacaan untuk } \\
\text { memperjelas isi buku } \\
\text { petunjuk }\end{array}$ \\
\hline
\end{tabular}

Saran dan komentar dari para ahli menjadi masukan untuk melakukan perbaikan terhadap buku petunjuk media pembelajaran IPA berbasis lingkungan pesisir yang telah dibuat. Tabel .menunjukkan hasil perbaikan dari revisi atau saran ahli.

\section{Tabel 14. Produk Sebelum dan Sesudah Revisi}

\begin{tabular}{|c|c|c|c|}
\hline Bagian & Sebelum Revisi & Setelah Revisi & Komentar Dan Saran \\
\hline Cover & 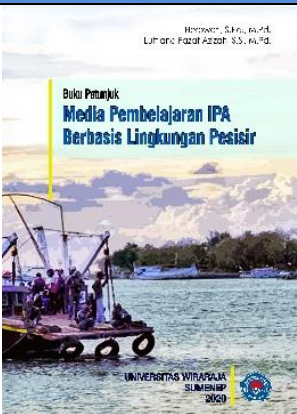 & 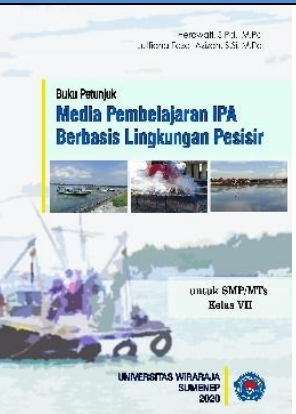 & $\begin{array}{l}\text { 1) Gambar/baground kelihatan } \\
\text { blur (pixelnya kecil) dapat di } \\
\text { filter atau ganti gambar yang } \\
\text { lebih bagus } \\
\text { 2) Tuliskan sasaran untuk kelas } \\
\text { berapa } \\
\text { 3) Bisa ditambahkan gambar- } \\
\text { gambar terkait } \\
\text { 4) Kontras font dan baground }\end{array}$ \\
\hline $\begin{array}{l}\text { Halaman } \\
\text { Sampul }\end{array}$ & $\begin{array}{l}\text { BUKU PE } \\
\text { MEDIA PEMBE }\end{array}$ & $\begin{array}{l}\text { BUKU PETUNJUK } \\
\text { MEDIA PEMBELAJARAN IPA }\end{array}$ & $\begin{array}{l}\text { 1) Pewarnaan halaman sampul } \\
\text { seharusnya lebih soft } \\
\text { dibandingkan cover } \\
\text { 2) Kontras font dan baground }\end{array}$ \\
\hline Prakata & 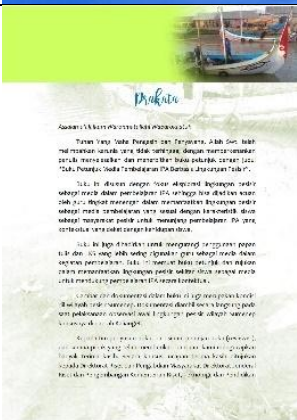 & 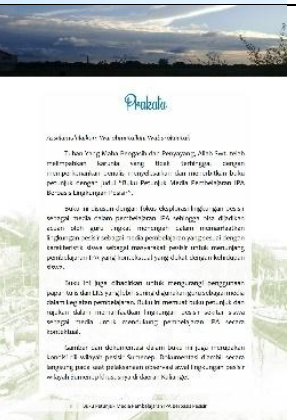 & $\begin{array}{l}\text { 1) Penggunaan font bersambung } \\
\text { diusahakan yang semi resmi } \\
\text { karena bukan buku fiksi } \\
\text { 2) Penggunaan gambar sebaiknya } \\
\text { disajikan full, karena } \\
\text { gambarnya seakan terpotong } \\
\text { 3) Kontras font dan baground } \\
\text { 4) Tambahkan halaman pada kata } \\
\text { pengantar dan daftar isi }\end{array}$ \\
\hline Daftar Isi & 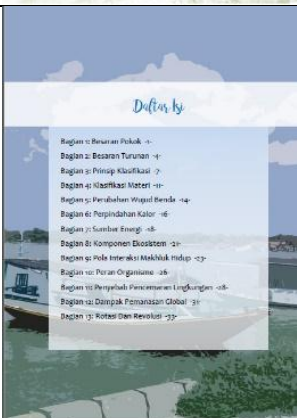 & 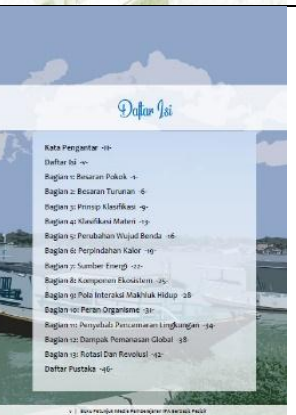 & $\begin{array}{l}\text { 1) Penggunaan font bersambung } \\
\text { diusahakan yang semi resmi } \\
\text { karena bukan buku fiksi } \\
\text { 2) Daftar isi minimal ditulis dari } \\
\text { kata pengantar } \\
\text { 3) Tambahkan halaman pada kata } \\
\text { pengantar dan daftar isi }\end{array}$ \\
\hline
\end{tabular}




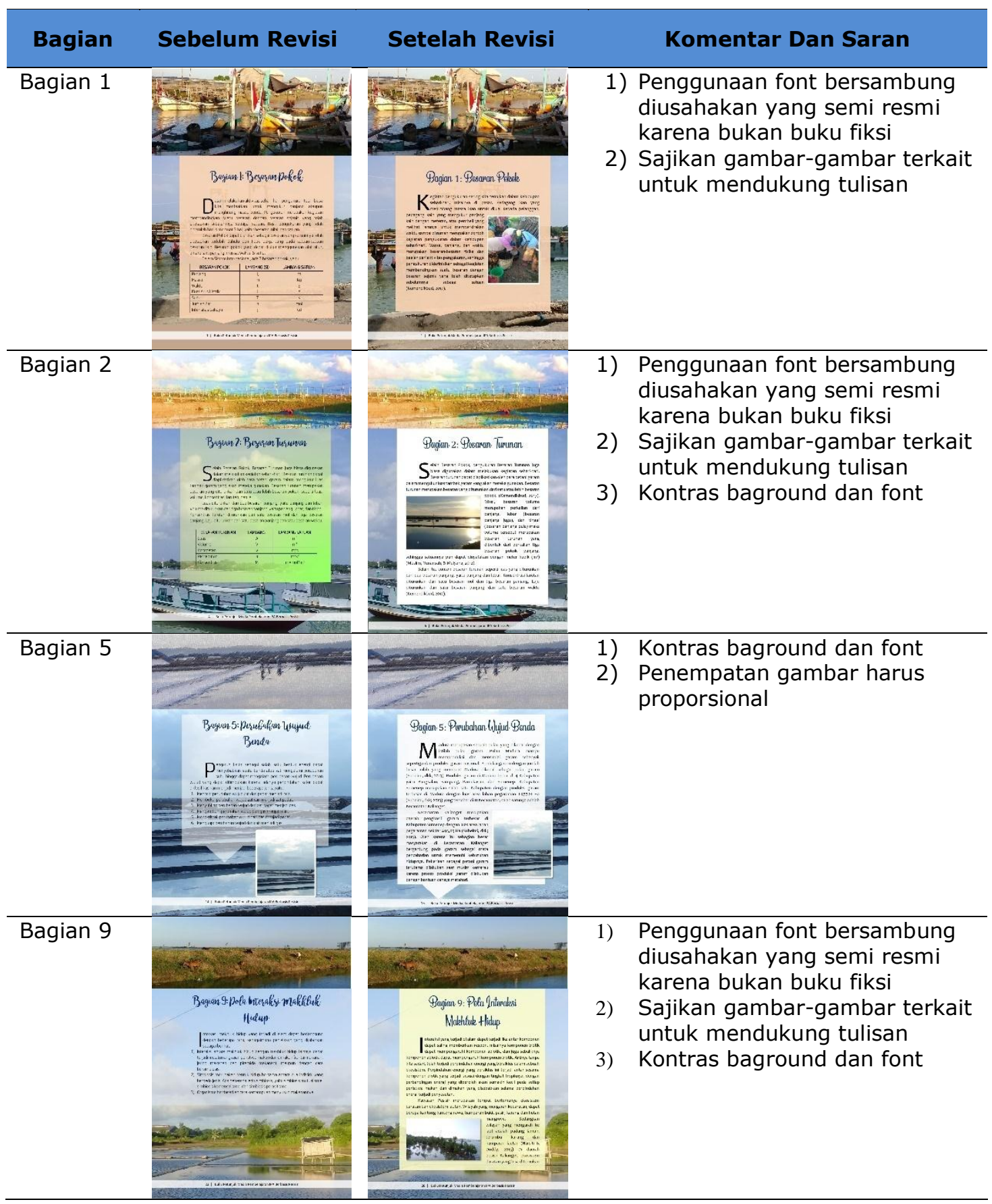

Sumber: Peneliti, diolah pada Oktober 2020

Kelayakan buku petunjuk media pembelajaran IPA berbasis lingkungan pesisir dilakukan penilaian pada kualitas isi materi dan divalidasi oleh ahli materi, dan aspek desain divalidasi oleh ahli desain. Aspek materi dan desain masing-masing terdiri dari 10 indikator. Kelayakan buku petunjuk media pembelajaran IPA berbasis lingkungan pesisir dilihat dari penilaian oleh ahli materi dan ahli desain. Hasil validasi aspek materi memperoleh rata-rata persentase sebesar $86 \%$ dengan kriteria sangat layak. Selain itu untuk mengetahui validitas materi produk dilakukan uji kesepakatan dari 3 validator menggunakan indeks validitas Aiken. Hasil uji kesepakatan 3 validator mendapatkan hasil 0,86 denga kategori tinggi atau sangat valid. Hasil aspek desain memperoleh rata-rata hasil persentase sebesar $95 \%$ dengan kriteria sangat layak. Berdasarkan hasil penilaian yang telah dilakukan, dapat dikatakan bahwa buku petunjuk media pembelajaran IPA berbasis lingkungan pesisir 
dikategorikan sangat layak dan dapat digunakan dalam pehasil penelitian pernyataan (Setiawan and Wiyardi, 2015) yang menyatakan bahwa suatu produk dapat dikatakan sangat layak jika mendapatkan nilai klasifikasi $81 \%$ sampai $100 \%$.

Buku petunjuk media pembelajaran IPA berbasis lingkungan pesisir dirancang inovatif serta mudah digunakan. Materi dirancang dengan keterkaitan antara materi IPA dengan eksplorasi lingkungan yang dilakukan di Kecamatan Kalianget. Karakteristik dari Buku petunjuk media pembelajaran IPA berbasis lingkungan pesisir yaitu adanya keterkaitan antara konsep IPA dengan lingkungan pesisir Kalianget yang disertai gambar nyata dari hasil observasi lapangan di 7 Desa yang ada di Kalianget. Buku petunjuk yang dibuat menggunakan bahasa yang mudah dipahami disertai adanya petunjuk bagi guru dalam mencari berbagai media yang relevan dengan lingkungan siswa. Bahasa merupakan salah satu bentuk komunikasi, baik lisan, tertulis atau tanda, yang didasarkan pada sistem simbol. Menurut Vygotsky, bahasa berperan untuk membentuk pemikiran seseorang. Perkembangan memori membuat siswa mengerti materi. Menurut teori pemprosesan informasi, suatu informasi dapat bertahan dalam memori jangka panjang (ingatan) jika diulangi terus-menerus atau digunakan dalam suatu aktivitas dalam kehidupan sehari-hari (Santrock, 2010).

Menurut (Habibi, Anekawati and Wati, 2012) Pembelajaran yang diarahkan sesuai dengan kultur dan kondisi lingkungan siswa sehari-hari akan membuat siswa memahami secara mendalam. Pembelajaran akan lebih bermakna jika disesuaikan dengan kehidupan sehari-hari sehingga siswa mampu mengaitkan konsep IPA dengan kemyataan yang ada di lingkungannya. Menurut teori belajar bermakna Ausubel, proses pembelajaran IPA akan lebih bermakna jika siswa dibuat untuk membangun konsep pemahamannya sendiri dengan menghubungkan pengalaman, peristiwa yang siswa temui dengan konsep IPA (Wisudawati and Sulistyowati, 2014).

4) Hasil Respon Guru

Uji coba awal berupa hasil wawancara guru tentang produk buku petunjuk secara umum. Uji coba kuantitatif data diperoleh dari respon guru melalui sebaran angket. Hasil uji coba akan digunakan untuk memperbaiki produk buku petunjuk.

Tahap uji coba awal dilakukan melalui wawancara pada 3 orang guru IPA. Berdasarkan Hasil wawancara didapatkan hasil bahwa (1) guru mengatakan urutan materi pada buku petunjuk tersusun secara sistematis, (2) guru menyatakan buku yang telah dibuat sangat membantu untuk menggunakan media pembelajaran IPA yang berbsis lingkungan pesisir, (3) guru menyatakan produk buku kerja yang dikembangkan menarik.

Tahap uji coba kuantitatif dilakukan dengan teknik penyebaran angket kepada 3 guru IPA dari sekolah yang berbeda. Hasil respon guru dapat dilihat pada Gambar 1 berikut.

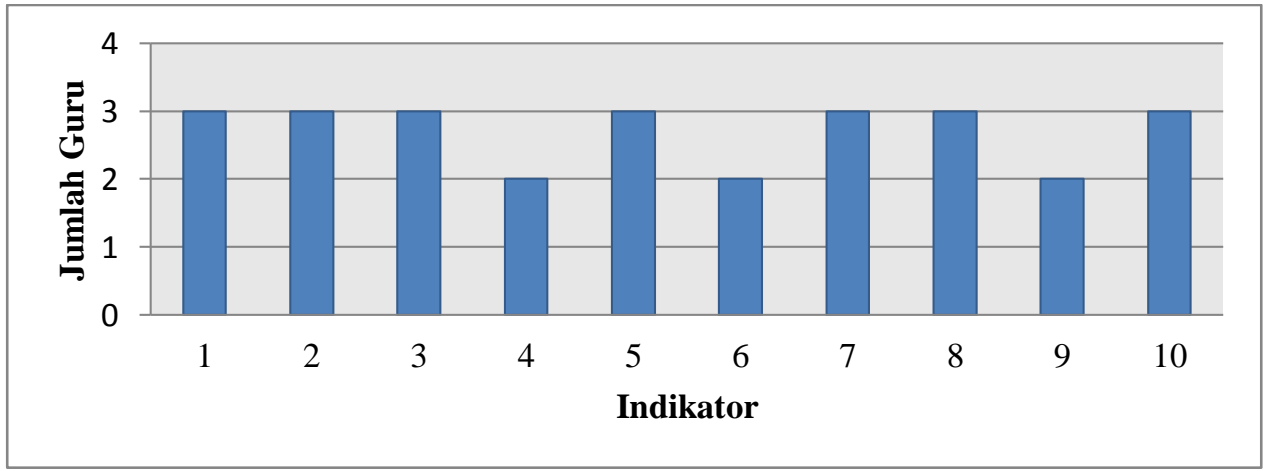

Gambar 1. Data Respon Guru pada Uji Coba Kuantitatif 


\section{Keterangan:}

1. Gambar yang digunakan memperjelas buku petunjuk media pembelajaran IPA berbasis lingkungan pesisir

2. Contoh kegiatan eksplorasi lingkungan pesisir pada buku petunjuk media pembelajaran IPA mudah ditemui di lingkungan siswa untuk mendukung pembelajaran IPA secara kontekstual

3. Penyajian materi pada buku petunjuk media pembelajaran IPA berbasis lingkungan pesisir tersusun sistematis

4. Tampilan buku petunjuk media pembelajaran IPA berbasis lingkungan pesisir menarik

5. Bahasa yang digunakan mudah dipahami

6. Buku petunjuk media pembelajaran IPA berbasis lingkungan pesisir mudah dibawa

7. Buku petunjuk media pembelajaran IPA berbasis lingkungan pesisir memfasilitasi guru untuk menggali informasi media yang ada di lingkungan pesisir

8. Buku petunjuk media pembelajaran IPA berbasis lingkungan pesisir membantu guru untuk menemukan media yang dibutuhkan dalam mendukung pembelajaran IPA secara kontekstual

9. Contoh eksplorasi lingkungan pesisir sebagai rujukan media pembelajaran yang ada di buku petunjuk media pembelajaran IPA berbasis lingkungan pesisir mudah ditemukan di lingkungan pesisir

10. Buku petunjuk media pembelajaran IPA berbasis lingkungan pesisir membantu guru untuk menerapkan pembelajaran IPA kontekstual berbasis lingkungan pesisir

Gambar 1 menunjukkan respon guru terhadap buku petunjuk media pembelajaran IPA berbasis lingkungan pesisir positif, karena rata-rata persentase nilai yang diperoleh yaitu $90 \%$ dengan kriteria sangat baik. Respon guru dalam penelitian ini berupa hasil penilaian guru terhadap produk yaitu melihat tampilan produk dan membaca isi produk. Oleh karena itu, guru juga di minta penilaian dalam bentuk skala Guttman. Guru juga diminta memberikan komentar dan saran untuk mengetahui seperti apa kesan mereka terhadap buku petunjuk media pembelajaran IPA berbasis lingkungan pesisir.

Berdasarkan hasil uji coba kuantitatif, respon guru terhadap buku petunjuk media pembelajaran IPA berbasis lingkungan pesisir mendapatkan persentase $90 \%$ dengan kategori sangat baik. Produk yang dikembangkan mengintegrasikan lingkungan tempat tinggal siswa sehingga membantu guru untuk menerapkan pembelajarn IPA yang relevan dengan kehidupan nyata siswa dan membuat pembelajaran lebih bermakna. Menurut (Widiadnyana, Sadia and Suastra, 2014) interaksi siswa dan lingkungan dapat meningkatkan pemahaman dan memperkaya pengetahuan serta dapat membantu siswa memiliki pemahaman yang lebih bermakna (Rasmiati, Azizah and Herowati, 2018). Buku petunjuk media memudahkan guru untuk mencari media yang sesuai dengan materi yang diajarkan.

Respon guru pada pada uji coba kuantitatif adalah respon positif. Selain karena banyak yang memberikan jawaban iya, juga memberikan komentar yang positif seperti buku petunjuk media menarik. Rata-rata guru menyatakan bahwa buku petunjuk media pembelajaran IPA berbasis lingkungan pesisir ini bagus. Hal tersebut sejalan dengan fungsi dari buku petunjuk yang dikemukakan oleh (Waluyo and Parmin, 2014) bahwa buku petunjuk media bertujuan untuk membantu guru melaksanakan kegiatan pembelajaran IPA. Seperti halnya buku petunjuk media pembelajaran IPA berbasis lingkungan pesisir ini yang dibuat dalam rangka untuk memudahkan guru dalam memanafaatkan lingkungan disekitar siswa sebagai media pembelajaran. 


\section{KESIMPULAN}

Lingkungan Kecamatan Kalianget pada umumnya dekat dengan daerah pantai sehingga sebagian besar di dominasi oleh keberadaan lahan tambak garam, perkebunan, dan ekosistem mangrove. Aktivitas siswa yang tinggal disekitarnya sebagian besar berkaitan dengan lingkungan pesisir termasuk mata pencaharian masyarakat. Kondisi lingkungan Kalianget dapat dikaitkan dengan pembelajaran IPA untuk kemudian dikembangkan menjadi buku petunjuk media pembelajaran IPA berbasis lingkungan pesisir. Kelayakan buku petunjuk dilihat dari hasil validasi materi memperoleh presentase $100 \%$, bahasa $88 \%$ dan desain $95 \%$ dengan kategori sangat layak sehingga buku petunjuk dapat digunakan.

\section{KETERBATASAN PENELITIAN}

Keterbatasan penelitian atas pengembangan buku petunjuk media pembelajaran IPA berbasis lingkungan pesisir adalah belum dilaksanakannya implementasi dan evaluasi dikarenakan keterbatasan waktu penelitian.

\section{SARAN}

Penelitian ini sebaiknya dilanjutkan dan diselesaikan sesuai rencana awal yaitu melakukan tahap implementasi dan evaluasi untuk mengetahui keefektifan penggunaan buku petunjuk oleh guru.

\section{DAFTAR PUSTAKA}

E. P. Permana and D. Nourmavita, "Pengembangan Multimedia Interaktif Pada Mata Pelajaran Ipa Materi Mendeskripsikan Daur Hidup Hewan Di Lingkungan Sekitar Siswa Kelas Iv Sekolah Dasar," J. PGSD J. IIm. Pendidik. Guru Sekol. Dasar, vol. 10, no. 2, pp. 79-85, 2017.

Habibi, Anekawati, A. and Wati, H. D. (2012) Pembelajaran IPA Berbasis Kultur Masyarakat Pesisir. Sumenep: FKIP Press.

Indriati and Riskiyah, "Pembelajaran Kontekstual Menggunakan Media Konkrit untuk Meningkatkan Hasil Belajar IPA Siswa Kelas IX pada Pokok Bahasan Wujud Benda di SMP Negeri 1 Dasuk," J. Lensa (Lentera Sains) J. Pendidik. IPA, vol. 7, no. 2, pp. 89-95, 2017.

Istitho'ah, "Pengembangan Media Pembelajaran Berbasis Kontekstual Berbantuan Software Cabri 3D dan Prezi dengan Teori Konstruktivisme pada Kubus dan Balok," AKSIOMA J. Mat. dan Pendidik. Mat., vol. 7, no. 2, pp. 10-23, 2016.

J. Handhika, "Efektivitas Media Pembelajaran IM3 Ditinjau dari Motivasi Belajar," J. Pendidik. IPA Indones., vol. 1, no. 2, pp. 109-114, 2012.

Mujiono, Puji. 2007. Kegiatan penilaian Buku Teks Pelajaran Pendidikan Dasar dan Menengah. Buletin BSNP, 1(2), pp 14-23. Available at: http://www.bsnpindonesia.org. (Accessed: 15 April 2019).

Musfiqon (2012) Pengembangan Media dan Sumber Pembelajaran. Jakarta: PT Prestasi Pustakaraya.

M. Pramita, S. Mulyati, and H. Susanto, "Implementasi Desain Pembelajaran pada Kurikulum 2013 dengan Pendekatan Kontekstual," J. Pendidik. Teor. Penelitian, dan Pengemb., vol. 1, no. 3, pp. 289-296, 2016. 
M. S. Zuhri and E. A. Rizaleni, "Pengembangan Media Lectora Inspire dengan Pendekatan Kontekstual pada Siswa SMA Kelas X," PYTHAGORAS, vol. 5, no. 2, pp. 113-119, 2016.

N. Septiana, M. Rohmadi, M. Nasir, L. R. Nastiti, Usmiyatun, and RIswanto, "Kesulitan Guru IPA SMP/MTs Mengajarkan IPA Terpadu di Kalimantan Tengah," EduSains J. Pendidik. Sains Mat., vol. 6, no. 1, pp. 1-11, 2018.

Puryono, dkk. 2019. Pengelolaan Pesisir dan Laut Berbasis Ekosistem. ISBN 978/979/097/595/8.

http://eprints.undip.ac.id/77815/1/Pengelolaan Pesisir dan Laut Cetak.pdf

Rasmiati, Azizah, L. F. and Herowati (2018) 'Pengembangan Petunjuk Praktikum IPA Berbasis Kultur Masyarakat Pesisir untuk Siswa Kelas VII SMPN 5 Sumenep', LENSA (Lentera Sains): Jurnal Pendidikan IPA, 8(1), pp. 38-53. Available at: http://jurnallensa.web.id/index.php/lensa/article/view/31 (Accessed: 29 March 2019).

Retnawati, Heri. 2015. Analisis Kuantitatif Instrumen Penelitian. Yogyakarta: Parama Publishing

R. Mutia, Adlim, and A. Halim, "Pengembangan Video Pembelajaran IPA Pada Materi Pencemaran Dan Kerusakan Lingkungan," J. Pendidik. Sains Indones. (Indonesian J. Sci. Educ., vol. 5, no. 2, pp. 108-114, 2017.

R. Prasetyo, S. Nurohman, and Susilowati, "Studi Kasus Kompetensi Pedagogik Guru IPA SMP Ditinjau dari Aspek PCK (Pedagogical Content Knowledge) dalam Implementasi Kurikulum 2013," J. Pendidik. Ilmu Pengetah. Alam, vol. 5, no. 9, pp. 17-23, 2016.

Santrock, J. W. (2010) Psikologi Pendidikan. Kedua. Jakarta: Kencana.

Suhelmi, dkk. 2013. Garam Madura. Jakarta: Pusat Penelitian dan Pengembangan Sumberdaya Laut Pesisir

Setiawan, H. W. and Wiyardi, R. S. (2015) 'Penggunaan App Inventor dalam Pembuatan Game Education Berbasis Android Sebagai Media Pembelajaran yang Mandiri dan Interaktif Untuk Meningkatkan Hasil Belajar Siswaa TITL Pada Pembelajaran Listrik Dasar SMK Muhammadiyah Majenang', Edu Elektrika Journal, 4(1). Available at: https://journal.unnes.ac.id/sju/index.php/eduel/article/view/7781.

Setyawan, Susilowati \& Sutarno. 2002. Biodiversitas Genetik, Spesies dan Ekosistem Mangrove di Jawa Petunjuk Praktikum Biodiversitas; Studi Kasus Mangrove. Surakarta: Kelompok Kerja Biodiversitas Jurusan Biologi Fakultas Matematika dan Ilmu Pengetahuan Alam Universitas Sebelas Maret.

Trianto (2015) Model Pembelajaran Terpadu Konsep, Strategi, dan Implementasinya dalam Kurikulum Tingkat Satuan Pendidikan (KTSP). Pertama. Jakarta: Bumi Aksara.

U. Sulfiah and D. Sulisworo, "Pengembangan Media Pembelajaran Kontekstual Menggunakan Komik Fisika untuk Peserta Didik SMP/MTs Kelas VII pada Pokok Bahasan Kalor," Berk. Fis. Indones., vol. 8, no. 2, pp. 31-37, 2016.

Waluyo, M. E. and Parmin, P. (2014) 'Pengembangan Panduan Praktikum IPA Terpadu Berbasis Inkuiri Terbimbing Tema Fotosintesis untuk Menumbuhkan 
Keterampilan Kerja Ilmiah Siswa SMP', Unnes Science Education Journal, 3(3), pp. 677-684. Available at: https://journal.unnes.ac.id/sju/index.php/usej/article/view/4286 (Accessed: 29 March 2019).

Widiadnyana, I. W., Sadia, W. and Suastra, W. (2014) 'Pengaruh Model Discovery Learning Terhadap Pemahaman Konsep IPA dan Sikap Ilmiah Siswa SMP', Jurnal Pendidikan dan Pembelajaran IPA Indonesia, 4(1). Available at: http://119.252.161.254/e-journal/index.php/jurnal_ipa/article/view/1344 (Accessed: 16 August 2019).

Wisudawati, A. W. and Sulistyowati, E. (2014) Metodologi Pembelajaran IPA. Jakarta: Bumi Aksara.

Wulandari, Y. (2017) 'KELAYAKAN ASPEK MATERI DAN MEDIA DALAM PENGEMBANGAN BUKU AJAR SASTRA LAMA', Gramatika STKIP PGRI Sumatera Barat, 3(2). doi: 10.22202/jg.2017.v3i2.2049. 